\title{
Investigation of the relationship between care burden and anxiety levels of terminal period patient relatives
}

\author{
Metin Yıldız', Yakup Sarpdağı ${ }^{2}$, Mehmet Salih Yıldırım³, Güray Okyar ${ }^{1}$ \\ ${ }^{\prime}$ Department of Nursing, School of Health, Agri Ibrahim Cecen University, Agri, Turkey \\ ${ }^{2}$ Public Health Nursing, Ataturk University, Erzurum, Turkey \\ ${ }^{3}$ Doğubayazıt Ahmed-i Hani Vocational School, Agri Ibrahim Cecen University, Agri, Turkey
}

Received: 2020-11-07.

Accepted: 2020-11-16

This work is licensed under a

Creative Commons Attribution 4.0 International License
J Clin Med Kaz 2021; 18(1):48-52

Corresponding author:

Metin Yıldız.

E-mail: yildizz.metin@gmail.com; ORCID: 0000-0003-0122-5677
Abstract

Objective: This research was carried out to examine the relationship between care burden and anxiety levels of terminal period patient relatives.

Material and methods: This research, which is planned as descriptive-correlational type, was conducted between March and May 2020 in Van Training and Research Hospital.

Results: According to the findings obtained from the study, the Beck Anxiety Inventory total score median of the individuals was determined to be 14.00. The total score median of the Zarit Care Burden Scale was determined to be 48.00. A positive statistically significant relationship was found between Beck Anxiety Inventory and Zarit Care Burden Scale total score medians $(p<0.05)$.

Conclusion: Individuals have been found to have moderate anxiety and "severe burden". Palliative care nurses should support the psychological and basic aspects of individuals with nursing interventions necessary for caregivers to cope with anxiety and feel less care burdens. It is recommended to carry out culture-specific programs and long-term clinical studies to ensure that caregivers are able to cope with anxiety.

Key words: anxiety, care burden, terminal period

\section{Introduction}

Palliative care service includes all the services provided to improve the quality of the remaining life of the individual receiving care. Palliative care reduces the burden experienced by the patient, caregivers and the patient's family $[1,2]$. Care for palliative care patients is usually provided by caregivers providing free services or someone who supplies the daily needs of the patient (for example, family member, friend, neighbor) (for example, bathing, dressing) [3]. Family members of palliative care patients care about the daily needs of various patients and have a close relationship with healthcare professionals. Multiple care needs of palliative patients can affect the health of caregivers [4]. As the disease progresses, a large number of physical, mental and cognitive and varying symptoms may create the need to provide care for family members or other caregivers. This responsibility is usually fulfilled by spouses or children and is often perceived as family responsibility [5]. For this reason, problems with aging affect not only the person in need of nursing but also family members and their relatives who care for them [6]. Despite the change in social structure, more than half of the responsibility of caring for the elderly is carried out by the family due to the strong family structure that continues in our country and developed countries [7]. Continuous care burden prevents the caregiver from taking enough time for himself and negatively affects mental health.

As a result, the caregiver experiences psychological problems such as unhappiness, restlessness, anxiety and depressive mood; cannot enjoy enough life and quality of life decreases [8]. Studies also reveal that caregivers have depression along with care burdens, physical, emotional and mental health impairments. Today, health problems arising due to old age and conditions such as anxiety, stress, psychosocial and behavioral changes arising due to the burden of caregivers are more frequently encountered [9]. In order to continue providing care, social, physical and mental needs of caregivers must be met. Caregivers also need health support. [10]. The number of studies evaluating the mental health and burden of care about the caregivers of the patients hospitalized in the palliative service is low. The mental state of the caregivers and the problems they face are 
sometimes overlooked by healthcare professionals. This study is planned to determine the level of anxiety in the caregivers and to support the people in need, and to shed light on future studies.

\section{Material and methods Study design}

This research, which is planned as descriptive-correlational type, was conducted between March and May 2020 in Van Training and Research Hospital.

The target population of the study consisted of individuals with terminal period patient at Van Training and Research Hospital, which located east of Turkey. The sample of the study consisted of individuals who have terminal period patients at Van Education and Research Hospital located in the east of Turkey, who meet the research criteria and agree to participate in the study.

\section{Collection of data}

In the collection of research data, Introductory Information Form, Beck Anxiety Inventory and Zarit Care Burden Scale were used. After explaining the purpose of the research, after obtaining verbal consent from those who voluntarily accepted to participate in the research, the data were collected online with the Google form prepared by the researchers.

\section{Data collection tools}

1. Introductory Information Form: It consists of questions created by researchers and containing the identifying features of individuals.

2. Beck Anxiety Inventory: It is a scale consisting of 21 items developed by Beck to measure anxiety symptoms and reveal the cognitive aspects of anxiety [11]. Ulusoy conducted the first validity and reliability studies of the scale (test-retestreliability coefficient $\mathrm{r}=0.57$ ). In line with the results of the study, it was stated that it can be used safely in anxiety rating and treatment monitoring studies [12]. It is a Likert type scale consisting of 21 items and scored between 0-3. For each item, "None", "'Mild Degree","'Medium Degree", "'Severely" options are required to be marked. The highest score is 63 points, the high score indicates the severity of anxiety and 0-7 points are no anxiety, 8-15 points are mild anxiety, 16-25 moderate anxiety and 26-63 points are divided into four categories. 13 items evaluate physiological symptoms, 5 items explain the direction of comprehension, 3 items symbolize both somatic and comprehension symptoms. In our study, the cronbach alpha value was found to be 0.92 .

3. Zarit Care Burden Scale: It was developed in 1980 by Zarit, Reever and Bach-Peterson [13]. It is a scale used to evaluate the problem experienced by the caregivers of the individual who needs care. The scale, which can be filled in by asking the caregivers themselves or by the researcher, consists of 22 statements that determine the effect of caregiving on the individual's life. The scale has a Likert type rating ranging from 1 to 5 like "never, rarely, sometimes, often or almost always". The high scale score indicates that the problem experienced was high. The scoring interval is between 0-88 and if the scores obtained are between 0-24 points, "light load"; "Moderate load" between 25-33 points; Between 34-88 points, it is evaluated as "severe load". The cronbach's alpha value of the scale was found to be 0.92 [13]. The Turkish validity and reliability study of the scale was conducted in 2008 by İnci and Erdem [14]. In our study, the cronbach alpha value was found to be 0.78 .

\section{Analysis of data}

The analysis of the data was done on the computer using the Statistical Package for the Social Sciences (SPSS-22) statistical software [15]. Frequency, descriptives, percentage, median and percentiles were used as descriptive statistical methods. MannWhitney $\mathrm{U}$ test was used for data that is not normally distributed for binary groups. Kruskal-Wallis test was used for data that is not normally distributed for groups more than two. Spearman correlation test was used to determine whether there is a linear relationship between the two numerical measurements, the direction and severity of this relationship, if any. In our study $(p<0.05)$, it was accepted as statistically significant difference.

\section{Ethical principles}

Ethical approval was obtained from Agr1 Ibrahim Cecen University Scientific Research Ethics Committee (Date: 27/02/2020 and number: 17) and written permission was obtained from the institutions where the study would be conducted. Verbal permission was obtained from those who wanted to participate in the research by making necessary explanations to the individuals included in the research.

\section{Results}

It was determined that $54.0 \%$ of the individuals participating in the study were female, $60.6 \%$ were single, $43.8 \%$ were secondary education graduates, $46.7 \%$ were income

Variables

\begin{tabular}{llll}
\hline \multirow{2}{*}{ Age (Year) } & Median & Percentile 25 & Percentile 75 \\
& 26 & 23.00 & 48.00 \\
\hline Gender & & $\mathrm{n}$ & $\%$ \\
& Female & 74 & 54.0 \\
Marital status & Male & 63 & 46.0 \\
& Single & 83 & 60.6 \\
\hline Education Level & Married & 54 & 39.4 \\
& Primary education & 44 & 32.1 \\
& Secondary education & 60 & 43.8 \\
\hline Income rate & High education & 33 & 24.1 \\
& Less than income & 39 & 28.5 \\
& Income equal to expense & 64 & 46.7 \\
\hline Family Type & More than income & 34 & 24.8 \\
& Nuclear family & 91 & 66.4 \\
\hline
\end{tabular}




\begin{tabular}{llll}
\hline & Median & Percentile 25 & Percentile 75 \\
\hline Beck Anxiety Inventory & 14.00 & 5.00 & 24.00 \\
\hline Zarit Care Burden Scale & 48.00 & 43.00 & 62.00 \\
\hline
\end{tabular}

The results are expressed as median and percentiles.

\begin{tabular}{|c|c|c|c|c|c|c|}
\hline Variables & & $\mathrm{n}$ & Median & Percentile 25 & Percentile 75 & Statistic \\
\hline \multirow[t]{2}{*}{ Gender } & Female & 74 & 20.00 & 10.00 & 24.00 & $\mathrm{U}=1747.0$ \\
\hline & Male & 63 & 10.00 & 4.00 & 24.00 & $P=0.011$ \\
\hline \multirow[t]{2}{*}{ Marital status } & Single & 83 & 10.00 & 4.00 & 23.00 & $\mathrm{U}=1894.0$ \\
\hline & Married & 54 & 20.00 & 6.00 & 24.00 & $\mathrm{P}=0.124$ \\
\hline \multirow[t]{3}{*}{ Education Level } & Primary education & 44 & 20.00 & 6.00 & 24.00 & $\mathrm{KW}=1.087$ \\
\hline & Secondary education & 60 & 12.00 & 4.00 & 24.00 & $\mathrm{P}=0.581$ \\
\hline & High education & 33 & 14.00 & 4.00 & 23.00 & \\
\hline \multirow[t]{3}{*}{ Income rate } & Less than income & 39 & 24.00 & 20.00 & 36.00 & $K W=15.754$ \\
\hline & Income equal to expense & 64 & 10.00 & 4.00 & 23.00 & $\mathrm{P}=0.000$ \\
\hline & More than income & 34 & 8.00 & 4.00 & 14.00 & \\
\hline Family Type & Nuclear family & 91 & 14.00 & 6.00 & 24.00 & $\mathrm{U}=1611.00$ \\
\hline
\end{tabular}

(The results are expressed as median and percentiles, Mann -Whitney U test, Kruskal Wallis Test and P-value).

\begin{tabular}{|c|c|c|c|c|c|c|}
\hline Variables & & $\mathrm{n}$ & Median & Percentile 25 & Percentile 75 & Statistic \\
\hline Gender & Female & 74 & 48.00 & 44.00 & 53.00 & $\mathrm{U}=2118.00$ \\
\hline & Male & 63 & 45.00 & 40.00 & 62.00 & $P=0.356$ \\
\hline Marital status & Single & 83 & 44.00 & 40.00 & 49.00 & $\mathrm{U}=1122.50$ \\
\hline & Married & 54 & 53.00 & 45.00 & 62.00 & $P=0.000$ \\
\hline Education Level & Primary education & 44 & 53.00 & 44.00 & 52.00 & $\mathrm{KW}=7.213$ \\
\hline & Secondary education & 60 & 46.00 & 42.00 & 63.00 & $P=0.027$ \\
\hline & High education & 33 & 47.00 & 40.00 & 48.00 & \\
\hline Income rate & Less than income & 39 & 62.00 & 48.00 & 71.00 & $K W=20.462$ \\
\hline & Income equal to expense & 64 & 45.00 & 42.00 & 59.75 & $\mathrm{P}=0.000$ \\
\hline & More than income & 34 & 45.50 & 39.00 & 50.00 & \\
\hline Family Type & Nuclear family & 91 & 48.00 & 45.00 & 62.00 & $\mathrm{U}=1540.00$ \\
\hline
\end{tabular}

(The results are expressed as median and percentiles, Mann -Whitney U Test, Kruskal Wallis Test and P-value).

\begin{tabular}{lllll}
\hline & & $(1)$ & $(2)$ & $(3)$ \\
\hline (1) Beck Anxiety Inventory & $\mathrm{r}$ & - & $.637^{*}$ & -.062 \\
& $\mathrm{p}$ & - & .015 & .474 \\
\hline (2) Zarit Care Burden Scale & $\mathrm{r}$ & $.637^{*}$ & - & -.040 \\
& $\mathrm{p}$ & .015 & - & .641 \\
\hline (3) Age (Year) & $\mathrm{r}$ & -.062 & -.040 & - \\
& $\mathrm{p}$ & .474 & .641 & - \\
\hline
\end{tabular}

(The results are expressed as Spearman Correlation Test).

is equal to the expense, $66.4 \%$ were nuclear family types and the median age of the group was 26 (Table 1).

According to the findings obtained from the study, the Beck Anxiety Inventory total score median of the individuals was determined to be 14.00. The total score median of the Zarit Care Burden Scale was determined to be 48.00 (Table 2).

Beck Anxiety Inventory total score median was found to be statistically significantly higher in women, in those whose 
income is less than their expenses and living in nuclear family type. $(\mathrm{p}<0.05)$ (Table 3$)$.

The total score median of the Zarit Care Burden Scale was found to be statistically significantly higher in married, primary school graduates, in those whose income is less than their expenses and living in the form of nuclear families $(p<0.05)$ (Table 4).

A positive statistically significant relationship was found between Beck Anxiety Inventory total score median and Zarit Care Burden Scale total score median. $(\mathrm{p}<0.05)$ (Table 5).

\section{Discussion}

Anxiety, stress and psychosocial changes can be observed due to the burden of caregivers [9]. In this section, findings about care loads and anxiety levels are discussed in the light of the literature.

According to the findings obtained from the study, it was determined that the total score median of the Beck Anxiety Inventory of the individuals was 14.00. In studies conducted, it was found that individuals, who undertake patient care, have an average level of emotions such as anxiety and sadness [16-18].

Beck Anxiety Inventory total score median was found to be statistically significantly higher in women $(p<0.05)$. Similar results were found in some studies $[19,20]$.

The Beck Anxiety Inventory total score median was found to be statistically significantly higher in those whose income was less than expense $(\mathrm{p}<0.05)$. In the study of Saritas and Buyukbayram, the average anxiety score of the caregivers was found higher in unemployed people with low economic level without social security [21]. In the study conducted by Alacacioglu, it was observed that the level of anxiety was higher in caregivers with low income level [22]. The fact that the income level is at a good level makes us think that the anxiety level will decrease due to the fact that the treatment expenses related to the disease are met and this will cause the caregivers to concentrate on the attention and support of the patient.

Beck Anxiety Inventory total score median was found to be statistically significantly higher in people living in nuclear family type $(\mathrm{p}<0.05)$. There is no similar study in the literature. It is thought that this situation increase the burden of care by the small number of family members and the experiences of the grandparents in the extended family are effective in experiencing emotionally less anxiety.

It was determined that the total score median of the Zarit Care Burden Scale was 48.00. Similar results have been found in many studies [23-25].

The total score median of the Zarit Care Burden Scale was found to be statistically significantly higher in the married ( $\mathrm{p}<$ 0.05 ). Similarly, in the study conducted by Tel et al, it was found that the care burden of the married people was higher [26].

The total score median of the Zarit Care Burden Scale was statistically significantly higher in primary school graduates $(\mathrm{p}<0.05)$. In the study conducted by Orak and Sezgin, it was determined that those with low education level among the caregivers had higher care burden [27]. According to these findings, it may be thought that people with low education level may have difficulties in obtaining information or other support from nurses and other health personnel and may have problems in socializing in carrying out the care process compared to more educated people.

The total score median of the Zarit Care Burden Scale was found to be statistically significantly higher in those whose income is less than their expenses $(p<0.05)$. Similar results were found in the study of Ozdemir et al. and in the study of Capik [28,29]. Giving care brings full-day responsibility to the individual and causes changes in the daily activities of families. Family members responsible for the patient; economic difficulties caused by the disease, changing the way of working, loss of income, may lead to restrictions in daily relationships with the family and social environment [30].

The total score median of the Zarit Care Burden Scale was found to be statistically significantly higher in people living in the nuclear family type $(\mathrm{p}<0.05)$. Contrary to our study, Tel et al's study was found high in the extended family [26]. Patriarchal and matriarchal family structure is now maintained even in the nuclear family structure. The proximity to the individual in need of care affects the responsibility of care. The responsibilities of individuals in the family differ even within themselves. It is thought that such a result occurred in our study due to the increase in the entry of mothers into the business life, higher expenses associated with care for the patient and the greater responsibility of each individual due to the small number of families compared to the extended family.

A positive statistically significant relationship was found between Beck Anxiety Inventory total score median and Zarit Care Burden Scale total score median $(\mathrm{p}<0.05)$. Many studies also show that those with higher care burden have higher anxiety levels [16-18,20,22]. Care burden levels and difficulties of caregivers suggest that individuals are affected by biopsychosocial aspects and uncertainty about their patients increases the level of anxiety.

\section{Conclusion}

According to the results of the research, it was determined that individuals have moderate anxiety and "severe burden". Palliative care nurses should support the psychological and basic aspects of individuals with nursing interventions necessary for caregivers to cope with anxiety and feel less care burdens. It is recommended to conduct culture-specific programs and longterm clinical studies to ensure that caregivers are able to cope with anxiety.

Disclosures: There is no conflict of interest for all authors.

Acknowledgments: The authors wish to thank all participants for engaging in this study.

Funding: No financial support was received by any of the authors for the research of this article. 


\section{References}

1. World Health Organization. WHO Definition of Palliative Care. 2002. http://www.who.int/cancer/palliative/definition/en/. Accessed Date: 03.04.2019.

2. Ferris FD, Gómez-Batiste X, Fürst CJ, Connor S. Implementing quality palliative care. Journal of pain and symptom management. 2007; 33(5):533-41. Doi:10.1016/j.jpainsymman.2007.02.033.

3. Reinhard SC, Given B, Petlick NH, Bemis A. Supporting family caregivers in providing care. Ed: Hughes RG, Patient Safety and Quality: An Evidence-Based Handbook for Nurses. AHRQ Publication, Rockville, USA; 2008. 1-64.

4. Kristjanson LJ, Aoun S. Palliative care for families: remembering the hidden patients. The Canadian Journal of Psychiatry. 2004; 49(6):359-65. Doi:10.1177/070674370404900604.

5. SullivanAB,MillerD. Whoistakingcareofthecaregiver?.Journalofpatientexperience.2015;2(1):7-12.Doi:10.1177/237437431500200103

6. Ringer T, Hazzan AA, Agarwal A, Mutsaers A, Papaioannou A. Relationship between family caregiver burden and physical frailty in older adults without dementia: a systematic review. Systematic reviews. 2017; 6(1):55. Doi:10.1186/s13643-017-0447-1

7. Iecovich E. Caregiving burden, community services, and quality of life of primary caregivers of frail elderly persons. Journal of Applied Gerontology. 2008; 27(3):309-30. Doi:10.1177/0733464808315289

8. Erdem M. Yaşlıya bakım verme. [in Turkish]. Anadolu Hemşirelik ve Sağlık Bilimleri Dergisi. 2005; 8(3):101-106.

9. Njoku GU. The impact of caring for seniors on the caregiver's stress level. Walden Universty, College of Health Sciences, Doctoral Study, Minneapolis 2015. https://pdfs.semanticscholar.org/bcb9/ff83ec308b6cb96d69989318efcdc694213b.pdf? $\mathrm{ga}=2.83136340 .396739371 .1562837509-298843409.1562837509$. (Accessed Date: 11.07.2019).

10. Judge KS, Bass DM, Snow AL, Wilson NL, Morgan R, Looman WJ, et al. Partners in dementia care: a care coordination intervention for individuals with dementia and their family caregivers. The Gerontologist. 2011; 51(2):261-72. Doi:10.1093/geront/gnq097.

11. Beck AT, Epstein N, Brown G, Steer RA. An inventory for measuring clinical anxiety: psychometric properties. Journal of consulting and clinical psychology. 1988; 56(6):893. Doi:10.1037/0022-006X.56.6.893

12. Ulusoy M, Şahin N, Erkman H. Turkish version of the Beck Anxiety Inventory: psychometric properties. Cognitive Psychotherapy Int Quaterly. 1998; 12:28-35.

13. Zarit SH, Reever KE, Bach-Peterson J. Relatives of the impaired elderly: correlates of feelings of burden. The gerontologist. 1980; 20(6):649-55. Doi:10.1093/geront/20.6.649.

14. İnci FH, Erdem M. Bakım verme yükü ölçeğinin türkçeye uyarlanması geçerlilik ve güvenilirliği. [in Turkish]. Atatürk Üniversitesi Hemşirelik Yüksekokulu Dergisi. 2008; 11(4):85-95.

15. Corp IB. IBM SPSS statistics for windows, version 22.0. Armonk, NY: IBM Corp. 2013.

16. Mancini J, Baumstarck-Barrau K, Simeoni MC, Grob JJ, Michel G, Tarpin C, LOUNDOU AD, Lambert A, Clément A, Auquier P. Quality of life in a heterogeneous sample of caregivers of cancer patients: an in-depth interview study. European Journal of Cancer Care. 2011; 20(4):483-92. Doi:10.1111/j.1365-2354.2010.01227.x

17. Toros F, Tot Ş, Düzovalı Ö. Kronik hastalığı olan çocuklar, anne ve babalarındaki depresyon ve anksiyete düzeyleri [in Turkish]. Klinik Psikiyatri. 2002; 5(4):240-7.

18. Chao CC, Chen SH, Wang CY, Wu YC, Yeh CH. Psychosocial adjustment among pediatric cancer patients and their parents. Psychiatry and clinical neurosciences. 2003; 57(1):75-81. Doi:10.1046/j.1440-1819.2003.01082.x

19. Amankwaa B. Informal caregiver stress. ABNF Journal. 2017; 28(4):92-5.

20. Arkın, S. Palyatif Bakım Hastalarına Bakım Verenlerde Anksiyete, Depresyon Ve Sosyal Destek Düzeylerinin İncelenmesi [in Turkish]. Tıpta Uzmanlık Tezi, Sağlık Bilimleri Üniversitesi - İzmir Tepecik Eğitim ve Araştırma Hastanesi, İzmir, 2017.

21. Sarıtaş SÇ, Büyükbayram Z. Kemoterapi alan hastaların ve bakım veren yakınlarının anksiyete düzeyleri ve etkileyen faktörler [in Turkish]. TAF Preventive Medicine Bulletin. 2016; 15(2).

22. Alacacıoğlu, A. Kanser hastaları ve hasta yakınlarının depresyon, umutsuzluk ve kaygı düzeylerinin değerlendirilmesi [in Turkish]. Doctoral dissertation, Dokuz Eylül Üniversitesi Tıp Fakültesi, 2007.

23. Johansen S, Cvancarova M, Ruland C. The effect of cancer patients' and their family caregivers' physical and emotional symptoms on caregiver burden. Cancer nursing. 2018; 41(2):91-9. Doi:10.1097/NCC.0000000000000493

24. Gröpper S, van der Meer E, Landes T, Bucher H, Stickel A, Goerling U. Assessing cancer-related distress in cancer patients and caregivers receiving outpatient psycho-oncological counseling. Supportive Care in Cancer. 2016; 24(5):2351-7. Doi:10.1007/s00520-015-3042-9

25. Karabulutlu, EY, Akyıl R, Karaman S, Karaca, M. Kanser hastalarına bakım verenlerin uyku kalitesi ve psikolojik sorunlarının incelenmesi [in Turkish]. Türk Onkoloji Dergisi. 2013; 28(1):1-9.

26. Tel H, Demirkol D, Kara S, Aydın D. KOAH'ı Hastaların Bakım Vericilerinde Bakım Yükü ve Yaşam Kalitesi [in Turkish]. Turk Toraks Dergisi/Turkish Thoracic Journal. 2012; 13(3). Doi:10.5152/ttd.2012.21

27. Orak OS, Sezgin S. Kanser Hastasına Bakım Veren Aile Bireylerinin Bakım Verme Yüklerinin Belirlenmesi [in Turkish]. Journal of Psychiatric Nursing/Psikiyatri Hemsireleri Dernegi. 2015; 6(1).

28. Özdemir FK, Şahin ZA, Küçük D. Kanserli çocuğu olan annelerin bakım verme yüklerinin belirlenmesi [in Turkish]. Yeni Tıp Dergisi. 2009; 26:153-158

29. Çapık, D. D. C. Epilepsili çocuğa sahip ebeveynlerin bakım yükü ve umutsuzluk düzeyinin incelenmesi [in Turkish]. Doctoral dissertation, 2018.

30. Ikeda T, Nagai T, Kato-Nishimura K, Mohri I, Taniike M. Sleep problems in physically disabled children and burden on caregivers. Brain and Development. 2012; 34(3):223-9. Doi:10.1016/j.braindev.2011.04.011. 